\title{
THE EFFECT OF SERVICE QUALITY ON THE HOSPITAL IMAGE IN
}

\section{BATAM}

\author{
Hajan Hidayat ${ }^{1)}$, Rizki Syafitri Lubis ${ }^{2)}$ \\ Accounting Department, Politeknik Negeri Batam \\ Jl. Ahmad Yani, Batam Centre, Batam 29461, Indonesia \\ ${ }^{1)}$ E-mail: hajan@polibatam.ac.id \\ ${ }^{2)}$ E-mail: rizkifitrilubis15@gmail.com
}

\begin{abstract}
The aims of this research to examine the effect of service quality on the hospital image in Batam through customer satisfaction as an intervening variable. Service quality was measured by quality dimensions namely: tangibles, reliability, responsiveness, emphaty, and assurance. Sampling method in this research using purposive sampling. Research objects is one public hospital and one private hospital in Batam with 196 sample respondents. The results of this research showed that service quality has a significant impact on hospital image through customer satisfaction as an intervening variable. Limitations of this research is the respondents only from the patients or visitors and only use one private hospital and one public hospital. Implications obtained in this research that service quality is good or bad will affect to customer satisfaction and it will be affect to image or impression of the customers toward hospital. The future studies may added samples not only in hospital but in other health care also.
\end{abstract}

\section{Keywords: Service Quality, Customer Satisfaction, Hospital Image}

\section{Introduction}

Public service is an important institution that ensures the passage of a state administration involving policy development and resourece management services from the public and for the public interest. Management derived from the public service will have consequences for accountable to the public and require openness and accountability to the public (Renyowijoyo, 2010). Providers of public services is a government agency which is divided into service units that directly provide services to the public. Measures of success ministry will look at the level community satisfaction received from the recepient of the service is based on expectations and their actual needs.

Health care is one of the public service that considered by the government in addition to education. This is because the health service covers every people and directly related to human needs. The success of a health development will affect the economic development of a region and increase the level of health of the individual productivity of each community also. The hospital is one of the places or facilities that provide public services such as health care services to the community. The growing of hospitals in Batam provides options for the public which hospitals that will provide a optimal health services in line with expectations or exceeded their expectations. According to Sugiarto in the article of Azizah Aisyati et al. (2007) a good service quality is able to provide sarisfaction service in order to fulfill the demands and expectations of consumers. In institution or service industry, community is inseperable from the competition between service providers one of which is the hospital. Many hospitals make efforts in order to gain the trust of the community by offering a from of service that quality and efficient. 
Therefore, we need a form of business to improve the quality of medical services because quality is the basis of survival of an agency (Widyaningsih, 2010). The reasons for selecting 1 private hospital and 1 public hospital in this study that there are no gaps in the election results later and the research object to represent a sample of hospitals in Batam by either private or public. The level of customer saticfaction in this case is the patient, the health care is an important factor in developing a system to better service as attentive to the needs of customers, minimize costs and time, and maximize the impact of theses services to customers. Health services naturally attractive because their services are to something that is not desirable, but on something that is needed in a particular point in time (Berry \& Beudapudi, 2007).

According Selvy et al. (2013) implementation of a quality service will create a good customer satisfaction, which will affect the company's image. Dimension of service quality can be well applied will affect the image of an institution to be positive in the eyes of the customer. Positive image of the institution which can increase the number of customers, retain customers and can earn the trust of customers. This study is an extension of a previous study conducted by Auka et al (2013) on the perceptions of service quality on customer loyalty in retail banks. Results from the study also showed that overall, the dimensions of service quality and reliability of empathy has the highest regression coefficient. The fundamental difference in this study with previous research conducted by Auka et al (2013) is located on the object of research is in the hospital sector. Differences of studies are also on changes in the dependent variable used is the company's image and the addition of intervening variables of customer satisfaction. This study aimed to determine the effect of service quality by using SERVQUAL model who developed by Parasuraman et al. (1988), namely: tangibles, reliability, responsiveness, assurance, and empathy for customer satisfaction, customer satisfaction to the image of the hospital, and the impact of service quality to the image of the hospital in Batam through customer satisfaction as an intervening variable.

\section{Theoretical Framework and Hypotheses}

\section{Development 2.1 Service Quality Theory}

Quality is a basic factor that can influence the choice of consumers for different types of services are developed at this time and has been one factor in the success and growth of an organization (Azizah, et al, 2007). If the services are received beyond what is expected by the customer, the quality of services can be defined as the quality of services ideal. Operationally, the quality of hospital services depends on the balance between perceptions and expectations of patients (Wu, 2011). In measuring the quality of services the researchers used a model of quality of service / services that many used the SERVQUAL model that consists tangibles, reliability, responsiveness, assurance, and empathy. Perceived service is technically a result of the views of consumers through service quality dimensions (Parasuraman, et al., 1988). tangibles is the ability of a company to demonstrate its existence to external parties. Capabilities and infrastructure for a reliable company and the circumstances surrounding neighborhood is a real physical evidence of the services provided by the service provider (Parasuraman, et al., 1988). Reliability in the SERVQUAL model is a service provider's ability to perform the promised service accurately, consistent, reliable, and accurate (Auka, et al., 2013). Responsiveness with regard to the staff's willingness to help customers and responding to their requests and informing at any time will be given and then provide services quickly (Parasuraman, et al., 1988). The assurance covers the knowledge, ability, courtesy, and trustworthiness owned by the staff free from danger, risk or doubt (Parasuraman et al.,1988). Empathy means enterprise customers understand the problem and act in the interest of the customer, and provide personal attention to our customers and have convenient hours of operation (Parasuraman, et al., 1988).

\subsection{Customer Satisfaction}

Customer satisfaction according to Kotler \& Keller (2007) is the level of one's feelings after comparing the performance (or result) that he perceived expectations and also stated that consumer behavior is defined as an action that is immediately accepted by consumers in 
obtaining, consuming, and using products or services, including the decision that precedes the action. Customer satisfaction can also be interpreted as a comparison between the services or results received consumers, the service received or the results must be at least equal to the expectations of consumers, or even surpass them (Selvy Normasari et al., 2013). Customer satisfaction can be seen from the attitude of customers who feel comfortable and confident in receiving the services rendered and provided by the service provider services. Security and comfort can be seen from the back of the patient's visit. Customer satisfaction may be a reflection of the quality of service provided by the service provider services. As expressed by Hekker et al in the article Wu (2011) which states that for the hospital sector, patient satisfaction becomes important because the patient will be fixed using medical services in hospitals is concerned, following the treatment plan recommended, and maintain relationship with the health care providers, and can recommend it to others.

\subsection{Hospital Image}

According to Kotler \& Keller (2007) image is the way the public perceives the (thinking) company or its products. Furthermore, there are three things that can make an effective identity, namely: building character and proportions of product value, embody the characters in a way that stands out, and exert emotional strength exceeds the mental image. Identity must be realized through any means of communication and contact brands that are available in order to function properly. Image is how the public (community) perceives the company. Companies designing identities that shape the image of the public, but other factors have to intervene in the image of any person against the company (Supranto \& Limakrisna, 2011). While the image of the company or institution according to the article Selvy Normasari et al. (2013) is an impression or mental impression or a picture of a company in the eyes of the audience formed based on their own knowledge and experience.

\subsection{Hypotheses Development}

The Effect of Service Quality on Customer Satisfaction

Service quality by Parasuraman et al. (1988) is a reflection or image evaluative perceptions of consumers with the services received at a particular time. Quality of service has a significant influence for a company because of good service quality can create customer satisfaction. Research Selvy Normasari et al. (2013) which states that there is a positive relationship between service quality and customer satisfaction. Similar results were also obtained from research Alrubaiee dan Alkaa'ida (2011) which states that service quality has a direct and positive effect on customer satisfaction, so the first hypothesis proposed in this study are:

$\mathrm{H}_{1}$ : The service quality has an influence on customer satisfaction..

\section{The Effect of Customer Satisfaction on Hospital Image}

Customer satisfaction reflects the feelings of the customer on the quality of service has been received, when a person is satisfied with the services provided, they will judge that the image of the good institution. Wu (2011) in research conducted in several hospitals in Taiwan showed a high level of patient satisfaction that can give you an idea that the good image of the hospital. Several previous studies have claimed that customer satisfaction influenced the image of the hospital. Previous studies have found a positive result or effect between customer satisfaction with hospital image (Marzaweny et al., 2012). It shows that the higher the satisfaction felt by the patient the higher the image of the hospital, so that the second hypothesis proposed in this study are:

$\mathrm{H}_{2}$ : Customer satisfaction has an influence on the image of the hospital institution.

\section{The Effect of Service Quality on The Hospital Image through Customer Satisfaction as an Intervening Variable}

Quality of service indirectly affect the hospital image with the mediating role of customer satisfaction. Customer satisfaction can be increased by improving the quality of service provided by the service provider services. Customer satisfaction can be the first effect achieved by the customer before the customer's own assessment of the impression or image that is acquired in the hospital, so customers are satisfied in accepting the 
services provided will strengthen the influence of service quality to the hospital image. Research conducted by Marzaweny et al. (2012) that service quality has a direct and positive influence on hospital image with evidence that patient satisfaction is mediating variables that play an important role in mediating the effect of service quality to the hospital image. Similar results were obtained from studies Mosahab et al. (2010) which states that customer satisfaction is able to mediate the impact of service quality to the hospital image, so the third hypothesis proposed in this study are:

$\mathrm{H}_{3}$ : The service quality has an influence on hospital image institution through customer satisfaction as an intervening varible.

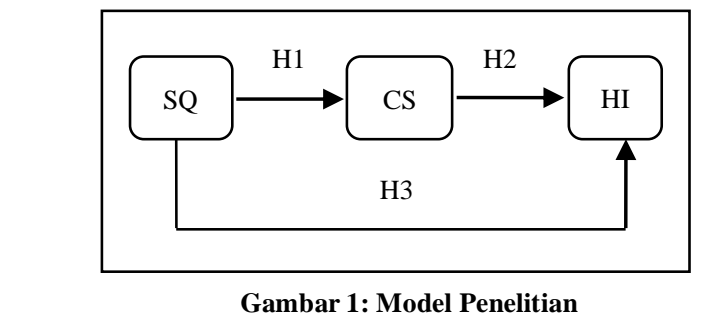

Source: Data Process

Information:

SQ: Service Quality

CS: Customer Satisfaction

HI: Hospital Image

\section{Research Model}

The method used in this research is quantitative method. This study will examine the impact of service quality by using SERVQUAL model developed by Parasuraman et al. (1988), namely: tangibles, reliability, responsiveness, assurance, and empathy on hospital image in Batam through customer satisfaction as an intervening variable

\subsection{Research Instruments}

The research instrument was a questionnaire given to respondents, inpatient and outpatient treatment of at least perform 1 time in the hospital in Batam. The questionnaire used in this study was adapted from Marzaweny, et al. (2012). Preparation of the questionnaire was based on theoretical been prepared previously and then developed into the grains have a question. Measurement methods of each variable used is a likert scale is a rating scale. This scale is used to measure the response of a subject into five (5) point scale with equal intervals (Hartono, 2015), that is $1=$ Strongly Disagree (STS), 2 = Disagree (TS), $3=$ Less Agree (KS), 4 = Agree (S), 5 = Strongly Agree (SS).

\subsection{Population and Sample}

The population in this study is 1 private hospital and 1 public hospital in Batam. This study uses a sampling technique purposive sampling. Purposive sampling technique to take samples of the population based on certain criteria. Criteria used in the sampling in this study were inpatients and outpatients were minimal perform one time treatment. To determine the number of samples from a population that has been set is required to produce a measurement sample size. Thus the researchers used tables Krejcie and Morgan with a total population of 395, the sample can be used as many as 196 .

TABLE 1

Total Research Sample

\begin{tabular}{lc}
\hline \multicolumn{1}{c}{ Information } & Total \\
\hline Questionnaires were distributed & 270 \\
Questionnaires was not returned from respondents & 64 \\
Questionnaires was returned from respondents & 201 \\
Questionnaires are not used & 5 \\
\hline Total sample in used & $\mathbf{1 9 6}$ \\
\hline Source: Data Process
\end{tabular}

\subsection{Variable Research dan Variable Measurement Dependent Variables}

The dependent variable in this study is the variable hospital image. Variable (Y) measured from each respondent whether good quality services provided by the hospital can give a good image for the hospital.

\section{Independent Variables}

Independent variables used in this study is the service quality variable consisting of tangibles, reliability, responsiveness, assurance, and empathy. Variable (X) measured from the assessment of a patient or visitor at the hospital. Variable (X) is measured by how the responses of patients or visitors of service quality to the impression or image of the hospital.

\section{Intervening Variables}

Intervening variables is a variable that affects the 
relationship between independent and dependent variables into direct and indirect relationships that can be observed and measured. Intervening variables used in this study is customer satisfaction. Variable (M) measured in comfort while in hospital, the service quick and precise, and easy administration procedures in patient acceptance.

\section{Research Result}

\subsection{Validity and Realiability Test}

Testing can be done through a research instrument validity test with Correlation Pearson and reliability tests with Cronbach Alpha. Validity test used to measure whether the questions in the questionnaire created can actually measure what is to be measured (Ghozali, 2011). The test of validity shows how real a test measures what it is supposed to measure. Significance test is done by compare the value of count $r$ with $r$ table. If $r$ count $>r$ table and a positive value then the questions or indicators are declared valid and otherwise also. Reliability testing showed the accuracy and precision of the measurement is also associated with the consistency of measurement (Hartono, 2015). To measure the reliability of statistical test used Cronbach Alpha (a). A construct or a variable value said to be reliable if the Cronbach Alpha $(a)>0.70$ Ghozali, 2011).

TABLE 2 Validity and Reliability Test Results

\begin{tabular}{lcc}
\multicolumn{1}{c}{ Variable } & $\begin{array}{c}\text { Pearson } \\
\text { Correlation }\end{array}$ & $\begin{array}{c}\text { Alpha } \\
\text { Cronbach }\end{array}$ \\
\hline Service Quality (X) & $0,780-0,926^{* *}$ & 0,951 \\
Customer Satisfaction (M) & $0,715-0,614^{* * *}$ & 0,779 \\
Hospital Image (Y) & $0,442-0,862^{*}$ & 0,821 \\
\hline
\end{tabular}

** Level of Significance 0,01

* Level of Significance 0,05

Source: Data Process

\subsection{Classical Assumptions Test Normality Test}

According Ghozali (2011), the normality test aims to test whether the regression model, the dependent variable and independent variables both have a normal distribution or not. Testing nomalitas can be seen through the Kolmogorov-Smirnov (K-S). Basis for a decision in the $\mathrm{K}-\mathrm{S}$ test is when the value of $\mathrm{sig}>0.05$, or $5 \%$, the data were normally distributed, and otherwise also.

TABLE 3

\begin{tabular}{lc}
\multicolumn{2}{c}{ Normality Test Results } \\
\cline { 2 - 2 } Angkatan & Presentase \\
\cline { 2 - 2 } Kolmogorov Smirnov Z & 0,062 \\
Assymp. Sig. (2-tailed) & 0,062 \\
\hline
\end{tabular}

Source: Data Process

Based test for normality by Kolmogorov-Smirnov 0.062 significance value greater than 0.05 . It can be concluded that the data were normally distributed.

\section{Multicollinearity Test}

Multicollinearity test was used to test whether the regression model found a correlation between independent variables and A good regression model should not happen correlation between the independent variable. To see multicoloniarity can be seen from the value of tolerance and VIF her. If the VIF value smaller than 10 and greater tolerance of 0.10 then there is no multicoloniarity.

TABLE 4

Multicollinearity Test Results

\begin{tabular}{lcc}
\hline \multirow{2}{*}{ Model } & \multicolumn{2}{c}{ Collinearity Statistics } \\
\cline { 2 - 3 } & Tolerance & VIF \\
\hline Service Quality & 0,862 & 1,161 \\
Customer Satisfaction & 0,862 & 1,161 \\
\hline
\end{tabular}

Source: Data Process

Based on Table 4 above, it can be seen that the data does not occur multikolinearitas. It can be seen from the tolerance of each independent variable is greater than 0.10 and VIF value of each variable is less than 10 .

\section{Heteroskidastity Test}

Ghozali (2011) heteroskedastisitas test aims to test whether the regression model occurred inequality variance from the residue of the observations to other observations. A good regression model is that Homoskesdasitas or did not happen Heterokesdatisitas. If the variance of the residuals of the observations to other observations remain, it is called and if different Homoskedastisitas called Heteroskidastity. Testing heteroscedasticity can be done using statistical testing, using methods Glejser Test. If the significance value> 0.05 , then there is no heteroscedasticity and $t$ is smaller than $\mathrm{t}$ table.

TABLE 5 


\begin{tabular}{lcc}
\multicolumn{3}{c}{ Heteroskidastity Test Result } \\
\hline \multicolumn{1}{c}{ Model } & t cout & Sig. \\
\hline Service Quality & $-1,897$ & 0,920 \\
Customer Satisfaction & $-1,319$ & 0,750 \\
\hline Source: Data Process &
\end{tabular}

Based on Table 5 above, it can be seen that the significant value of service quality and customer satisfaction 0.750 0.920 greater than 0.05 and $t$ obtained values of quality service and customer satisfaction by $-1.897-1.319$ smaller than $\mathrm{t}$ table amounted to 1,9721 so that the data can be concluded free from heterokedastisitas.

\subsection{Hypothesis Testing}

Hypothesis testing is performed to detect the influence of an intervening variable in mediating the independent variable on the dependent variable used Regression Analysis method, Path Analysis and Sobel Test. Path analysis is an extension of multiple regression analysis, or in other words the path analysis is the use of regression analysis to estimate the causal relationships between variables predetermined by the theory.

\section{Regression Analysis}

Linear regression analysis is used to determine the direction of the relationship between independent variables intervening, and intervening variables with the dependent variable.

\section{Different T-test Test}

$\mathrm{T}$ tests were performed to test the significance level of influence of independent variables on the dependent variable partially with a confidence level of $95 \%(\alpha=$ $0.05)$.

TABLE 6 Hypothesis 1 Test Results

\begin{tabular}{lccc}
\hline & Coefficients & T & Sig. \\
\hline Constant & 14,036 & 4,851 & 0,000 \\
Service Quality & 0.190 & 5,583 & 0,000 \\
\hline Source: Data Process & & &
\end{tabular}

From the results of the first output $t$ test can be seen that for service quality variable obtained $t$ arithmetic amounted to 5.583 with 0.000 significance value $<0.05$ so that it can be concluded that the $\mathrm{H} 1$ supported that affect service quality to customer satisfaction. From the results of hypothesis testing table 1 above can be created regression equation as follows:

$\mathrm{CS}=14.036+0.190 \mathrm{SQ}+\varepsilon$

TABLE 7

Hypothesis 2 Test Results

\begin{tabular}{lccc}
\hline & Coefficients & T & Sig. \\
\hline Constant & 14,509 & 9,280 & 0,000 \\
Service Quality & 0.121 & 6,440 & 0,000 \\
Customer Satisfaction & 0,090 & 2,456 & 0,015 \\
\hline Source: Data Process & & &
\end{tabular}

From the results of the $t$ test that both can be seen that for the quality of services obtained t calculate equal to 6.440 with 0.000 significance value of $<0.05$ so that it can be concluded that the quality of service affect the image of the hospital. As for customer satisfaction variables obtained t count 2,456 with significant value $0.015<0.05$ so that it can be concluded that the $\mathrm{H} 2$ supported that customer satisfaction influenced the image of the hospital. From the results of hypothesis testing table 2 above can be prepared regression equation as follows:

$\mathrm{HI}=14,509+0,121 \mathrm{SQ}+0,090 \mathrm{CS}+\varepsilon$

\section{Path Analysis}

Path analysis was used to test the effect of intervening variables. The path coefficients calculated by making structural equation is a regression equation showing the relationship hypothesized, as follows:

(1) $\mathrm{CS}=14,036+0,190 \mathrm{SQ}+\varepsilon$

(2) $\mathrm{HI}=14,509++0,121 \mathrm{SQ}+0,090 \mathrm{CS}+\varepsilon$

The influence of the independent variable on the dependent variable via an intervening variable using path analysis can be seen as follows:

TABLE 8

Value Effect Based on Path Analysis

\begin{tabular}{cccc}
\hline Information & $\begin{array}{c}\text { Dirrect } \\
\text { Effect }\end{array}$ & Indirect Effect & Total Effect \\
\hline $\mathrm{X} 1->\mathrm{Y}$ & $\mathrm{p} 1=0,121$ & $\mathrm{p} 2 \times \mathrm{p} 3=0,0171$ & 0,1381
\end{tabular}

Source: Data Process

\section{Sobel Test}

Sobel calculation used to test whether the effect of indirect mediation by multiplying coefficient (p2 x p3) is 
significant or not. The following calculation is based on the value of the effect of mediation path analysis:

$\mathrm{Sab}=$ $\sqrt{(0,090)^{2}(0,034)^{2}+(0,190)^{2}(0,037)^{2}+(0,034)^{2}(0,037)}$

$$
=0,0077696244
$$

Based on the calculation above, the value of $t$ arithmetic to test the effect of intervening variables with the formula as follows:

\section{$\mathrm{t}=2,2008785907334$}

Therefore $\mathrm{t}=2.2$ is greater than $\mathrm{t}$ table with a significance level of 0.05 is equal to 1.9721 , it can be concluded that the mediation coefficient of 0.0171 is significant and means that there are significant mediation. With the mediation of the effect it can be concluded that the $\mathrm{H} 3$ is supported explaining that there is influence between quality of service to the hospital's image through customer satisfaction as an intervening variable.

\subsection{Discussion}

\section{The Effect of Service Quality on Customer Satisfaction}

Based on $t$ test results that we can know that for service quality variable obtained $t$ arithmetic amounted to 5.583 with 0.000 significance value $<0.05$ so that it can be concluded that $\mathrm{H} 1$ is supported quality of service has an influence on customer satisfaction. These results indicate that customer satisfaction is affected by the quality of service provided, since individuals in this study were hospital patients feel that the quality of services provided will improve customer satisfaction when receiving good service or quality as from the atmosphere and attitude of the staff or employees were friendly and able to respond quickly and precisely to the customer. The results are consistent with the theory of Parasuraman et al. (1988) which states that service quality is a reflection or image evaluative perceptions of consumers with the services received at a certain time and have a significant influence for a company because of good service quality can create customer satisfaction. The results are consistent with research conducted by Selvy Normasari et al. (2013) and Alrubaiee \& Alkaa'ida (2011) who found that service quality effect on customer satisfaction.

\section{The Effect of Customer Satisfaction on Hospital Image}

Based on $\mathrm{t}$ test results that we can know that for service quality variable obtained $t$ arithmetic amounted to 6.440 with 0.000 significance value of $<0.05$ so that it can be concluded that the $\mathrm{H} 2$ is supported quality of service affect the image of the hospital. These results indicate that the image of the hospital affected by customer satisfaction. Customer satisfaction reflects the feelings of the customer on the quality of service has been received, when a person is satisfied with the services provided, they will judge that the image of the intansi good and the higher the satisfaction felt by the patient or the higher the better the image of the hospital. This is consistent with the theory Kotler \& Keller (2007) which states that customer satisfaction is the satisfaction level of someone after comparing the performance or results which he perceived expectations. The results are consistent with research conducted by Marzaweny et. al. (2012) and Wu (2011) who found that customer satisfaction influenced the image of the hospital.

\section{The Effect of Service Quality on Hospital Image through Customer Satisfaction as an Intervening Variable}

Based on the results of the path analysis and calculations obtained Sobel $t=2.2>t$ table with a significance level of 0.05 is equal to 1.9721 , it can be concluded that the mediation coefficient of 0.0171 is significant and means that there are significant mediation. With the mediation of the effect it can be concluded that the $\mathrm{H} 3$ is supported that there is influence between quality of service to the hospital's image through customer satisfaction as an intervening variable. This suggests that service quality indirectly affect the image of the hospital with the mediating role of customer satisfaction. Customer satisfaction can be increased by improving the quality of service provided by the service provider services. The better the quality of services provided, the customer satisfaction will increase and affect the image of the hospital. The results of this study in accordance with the theory of Kotler and Keller (2007) which states that the image is the way the public perceives the (thinking) company or its products and in line with research 
Marzaweny et. al. (2012) and Mosahab et. al (2010), which also found the result that the quality of service affect the image of the hospital with customer satisfaction as an intervening variable.

\section{Conclusion}

This study aimed to determine the effect of service quality by using the SERVQUAL model that developed by Parasuraman et al. (1988) namely: tangibles reliability, responsiveness, assurance, and empathy on customer satisfaction, customer satisfaction one hospital image, and the effect of service quality on the hospital image in Batam through customer satisfaction as an intervening variable. The test results showed that the service quality affect the hospital image with satisfaction as an intervening variable.

The hospital is one of the places or facilities that provide public services such as health care services to the community. The growing number of hospitals in Batam provides options for public hospitals which will provide optimal health services in line with expectations or exceeded their expectations. The provision of optimal service quality of a hospital can improve customer satisfaction so that the hospital will get a good image of the customer. The findings of this study indicate that the hospital image in Batam based on the frequency distribution of respondents hospital image variables are good enough and of dimensions of service quality dimensions tangibles, reliability, and guarantees the most good.

This study has limitations which are confined to institutions hospital services and does not involve other agencies such as health care, neighborhood health center, clinic, health center, etc. Sample this study only patients in 1 private hospital and 1 public hospital. Further research can be examined by adding the number of samples used in the study are not only customers but from the management at the institution. Adding object of research not only in the institution hospital but other health care institutions.

\section{Refference}

Adisaputro, G. (2014). Manajemen Pemasaran. Yogyakarta: UPP STIM YKPN.

Alrubaiee, L., \& Alkaa'ida, F. (2011). The Mediating
Effect of Patient Satisfaction in the Patients Perceptions of Healthcare Quality - Patient Trust Relationship. International Journal of Marketing Studies , 3 (1).

Auka, D. O., Bosire, J. N., \& Matern, V. (2013). Perceived Service Quality and Customer Loyalty in Retail Banking in Kenya. British Journal of Marketing Studies , 1, 32.

Azizah Aisyati, T. R. (2007). Analisa Kualitas Pelayanan Rumah Sakit Umum Daerah (RSSUD) Wonogiri Menggunakan Metode Fuzzy-Servqual. Gema Teknik, 1.

Ghozali, I. (2011). Aplikasi Analisis Multivariate dengan Program IBM SPSS 20. Semarang: Badan Penerbit Universitas Diponerogo.

Hartono, J. (2015). Salah Kaprah dan Pengalaman-Pengalaman (6 ed.). Yogyakarta: BPFE.

Kotler, P., \& Keller, K. L. (2007). Manajemen Pemasaran (Vol. 12). (J. Purba, Penyunt., \& B. Molan, Penerj.) Indonesia: PT. MACANAN JAYA CEMERLANG.

Marzaweny, D., Hadiwidjojo, D., \& Chandra, T. (2012). Kepuasan Pasien sebagai Mediasi Pengaruh Kualitas Pelayanan Kesehatan terhadap Citra Rumah Sakit Umum Daerah (RSUD) Arifin Achmad Pekanbaru. Jurnal Aplikasi Manajemen , $10(3)$

Parasuraman, A., Zeithaml, V. A., \& Berry, L. L. (1988). SERVQUAL : A Multiple-Item Scale for Measuring Consumer Perceptions of Service Quality. Journal of Retailing .

Renyowijoyo, M. (2010). Akuntansi Sektor Publik. Jakarta: Mitra Wacana Media.

Supranto, J., \& Limakrisna, H. N. (2011). Perilaku Konsumen \& Strategi Pemasaran Untuk Memenangkan Persaingan Bisnis (2 ed.). Jakarta: Mitra Wacana Media.

Selvy Normasari, S. K. (2013). Pengaruh Kualitas Pelayanan Terhadap Kepuasan Pelanggan, Citra Perusahaan, dan Loyalitas Pelanggan. Jurnal Administrasi Bisni , 6, 2 ..

Widyaningsih, W. (2010). Analisis Harapan dan Persepsi Kualitas Jasa Pelayanan Kesehatan Terhadap Kepuasan Pasien di Instalasi Rawat Jalan RSUD Ambarawa.

Wu, C.C (2011). The Impact of Hospital Brand Image on Service Quality, Patient Satisfaction, and Loyalty. African Journal of Business Management , 5 (12) 